\title{
Single subject research: Pembelajaran phytagoras pada siswa introvert kelas VIII
}

\author{
Oktavia Filda Yanti, Rully Charitas Indra Prahmana ${ }^{1}$, Fitriyah ${ }^{2}$
}

\begin{abstract}
Abstrak: Penelitian ini bertujuan untuk menganalisis proses pembelajaran siswa introvert pada materi Phytagoras dan hasil perlakuan dengan problem-based learning (PBL) terhadap kemampuan berpikir kritis matematis siswa. Penelitian kuantitatif deskriptif dengan desain Single Subject Research (SSR) A-B digunakan untuk mencapai tujuan penelitian tersebut. Subjek dalam penelitian ini adalah seorang siswa kelas VIII SMP. Data dikumpulkan melalui tes, observasi, dan wawancara. Selanjutnya, data yang dikumpulkan dianalisis berdasarkan dua kondisi besar selama proses penelitian, yaitu analisis dalam kondisi dan antar kondisi. Analisis dalam kondisi meliputi komponen panjang kondisi (panjang interval), kecenderungan arah, tingkat stabilitas, tingkat perubahan, jejak data, dan rentang. Analisis antar kondisi meliputi jumlah variable yang diubah, perubahan kecenderungan arah dan efeknya, perubahan stabilitas dan efeknya, perubahan level data, serta data yang tumpang tindih (overlap). Hasil penelitian menunjukkan bahwa PBL memiliki peran yang sangat besar selama proses pembelajaran karena mendukung siswa introvert untuk aktif dalam menyelesaikan permasalahanpermasalahan kontekstual yang diberikan, sehingga pada akhir pembelajaran kemampuan berpikir kritis matematis siswa tersebut dapat ditingkatkan.
\end{abstract}

Kata kunci: Berpikir Kritis; Introvert; Single Subject Research; Problembased Learning

\begin{abstract}
The research aimed to analyze how introvert student learn Phytagoras topic and the result of learning intervention using problembased learning (PBL) on the student's mathematical critical thinking ability. Descriptive quantitative research with single subject design was used to achieve the aims of the research. The subject was an introvert student of grade VIII. Data was collected through test, observation, and interview. Data analysis was based on two major conditions during the research, i.e. within-conditions and inter-conditions. Within-condition analysis included interval length, direction tendency, stability level,
\end{abstract}

\footnotetext{
1 Universitas Ahmad Dahlan, Yogyakarta, Indonesia, rully.indra@mpmat.uad.ac.id

2 SMPN 3 Sewon, Bantul, Yogyakarta, Indonesia
} 
rate of change, data trace, and range. Meanwhile, inter-condition analysis comprised the number of variables changed, changes in direction and effect trends, changes in stability and its effects, changes in data levels, and overlap data. The research showed that PBL has a significant role during the learning process since it supports the subject to be active in solving the contextual problems. In this case, the mathematical critical thinking ability can be developed and improved.

Keywords: Critical Thinking; Introvert; Single Subject Research; Problem-based Learning

\section{A. Pendahuluan}

Kemampuan berpikir kritis merupakan kemampuan dalam mengidentifikasi kebenaran suatu fakta, menalar, menganalisis fakta, mengevaluasi, serta kemampuan memecahkan masalah secara logis sehingga menghasilkan sebuah kesimpulan yang benar (Anwar, Sa'dijah, \& Subanji, 2017). Hal ini senada dengan Arifin (2016) yang mengungkapkan bahwa kemampuan berpikir kritis adalah kemampuan berpikir tingkat tinggi berupa kecermatan dalam menganalisis dan mempertimbangkan solusi yang diperoleh dalam menyelesaikan suatu permasalahan. Oleh karena itu, kemampuan berpikir kritis penting dimiliki oleh siswa agar cermat dalam memecahkan masalah sehingga memperoleh solusi yang tepat.

Sunarsih (2012) menyatakan bahwa siswa dengan kepribadian introvert selalu merasa malu, rendah diri, dan memiliki perasaan takut ketika dihadapkan pada hal-hal baru. Seseorang dengan kepribadian introvert menentukan pikiran, perasaan dan tindakannya melalui faktor subjektif yang menyebabkan kurang baiknya penyesuaian dengan dunia luar (Hasanah \& Sutrima, 2013). Hasil penelitian Naafidza dan Arief (2016) menunjukkan bahwa siswa introvert cenderung masuk dalam kriteria tingkat berpikir kritis 2 (TBK 2) dan tingkat berpikir kritis 3 (TBK 3), yaitu siswa mampu mengungkapkan fakta yang dibutuhkan dalam menyelesaikan suatu masalah; mampu memilih argumen logis, relevan, akurat; dan mampu mendeteksi bias (kekeliruan) berdasarkan sudut pandang yang berbeda (TBK 2) dan merumuskan pokok-pokok permasalahan; mengungkapkan fakta yang dibutuhkan dalam menyelesaikan suatu masalah; mampu memilih argumen logis, relevan, 
dan akurat; mampu mendeteksi bias (kekeliruan) berdasarkan sudut pandang yang berbeda; dan menentukan akibat dari suatu pernyataan yang diambil sebagai suatu keputusan (TBK 3). Selanjutnya, sejumlah peneliti telah mendokumentasikan hasil penelitian mereka terkait profil siswa introvert dalam pembelajaran matematika (Yuwono, 2010; Hasanah, Mardiyana, \& Sutrima, 2013; Anggraeni \& Khabibah, 2014). Yuwono (2010) menyatakan tiap tipe kepribadian siswa memiliki cara yang berbeda dalam menyelesaikan setiap permasalahan yang diberikan. Hal ini sejalan dengan hasil penelitian Hasanah, et al. (2013) dan Anggraeni, et al. (2014) yang menyatakan bahwa kemampuan matematis siswa introvert dapat ditingkatkan menggunakan permasalahan kontekstual. Namun, sejumlah penelitian tersebut memiliki fokus secara umum karena menggunakan satu kelas sampel penelitian dengan berbagai jenis kepribadian siswa didalamnya, sehingga penelitian ini dilakukan hanya terfokus pada intervensi terhadap satu siswa yang memiliki kepribadian introvert untuk melihat kemampuan matematis siswa tersebut. Oleh karena itu, penelitian ini penting dilakukan untuk melihat kemampuan matematis siswa introvert lebih mendalam karena di disain lebih personal (individu).

Sebagian guru matematika masih menerapkan pembelajaran konvensional yaitu pembelajaran yang diterapkan secara umum di sekolah dalam hal ini pembelajaran yang menggunakan metode ceramah, sehingga mengakibatkan rendahnya kemampuan berpikir kritis matematis siswa (Fatmawati \& Triyanto, 2014). Sejalan dengan itu, Syahbana (2012) mengemukakan bahwa siswa belum mempunyai kemampuan berpikir kritis matematis disebabkan oleh guru di Indonesia yang pada umumnya hanya meminta siswa untuk mendefinisikan, mendeskripsikan, menceritakan kembali, menguraikan, dan mendaftar materi yang dipelajarinya. Selanjutnya, Marwan dan Ikhsan (2016) mengemukakan bahwa akibat dari pembelajaran konvensional yang hanya menekankan pada tuntutan kurikulum adalah rendahnya kemampuan berpikir kritis siswa. Oleh sebab itu, salah satu penyebab rendahnya kemampuan berpikir kritis siswa adalah pada kondisi sekolah yang masih menggunakan pembelajaran konvensional.

PBL merupakan pembelajaran yang menggunakan masalah autentik sebagai sumber belajar yang dapat melatih kemampuan berpikir kritis 
matematis dan mengembangkan kepribadian siswa melalui masalah dalam kehidupan sehari-hari (Novitawati \& Irfan, 2014). Selanjutnya, Marwan, et al. (2016) menyatakan bahwa salah satu cara untuk meningkatkan kemampuan berpikir kritis adalah dengan mengganti proses pembelajaran konvensional dengan PBL. Selain itu, Cahdriyana (2016) mengungkapkan bahwa PBL dapat melatih siswa untuk berpikir tingkat tinggi dan terampil dalam menyelesaikan suatu permasalahan yang dihadapi. Oleh sebab itu, proses pembelajaran konvensional di sekolah dapat diganti dengan PBL untuk melatih siswa dengan kepribadian introvert dalam berpikir kritis matematis .

Berdasarkan penelitian pendahuluan yang dilakukan oleh Yanti dan Prahmana (2017) menunjukkan bahwa model PBL dapat meningkatkan kemampuan berpikir kritis matematis siswa. Oleh karena itu, peneliti tertarik untuk mengimplementasikan model PBL pada siswa dengan kepribadian introvert pada materi teorema Phytagoras, sehingga hasil penelitian ini dapat menjelaskan proses pembelajaran yang dapat memberikan pengaruh terhadap kemampuan berpikir kritis matematis siswa introvert.

\section{B. Metode Penelitian}

Jenis penelitian yang digunakan dalam penelitian ini yaitu kuantitatif deskriptif berupa penelitian subjek tunggal atau SSR. Desain penelitian SSR yang digunakan dalam penelitian ini, yaitu A-B. Desain A-B merupakan desain dasar dari penelitian SSR (Sunanto, Takeuchi, \& Nakata, 2006). Penelitian SSR ini dilaksanakan di SMP Negeri 3 Sewon. SMP Negeri 3 Sewon beralamat di Jalan Bantul, Pendowoharjo, Kecamatan Sewon, Kabupaten Bantul, Daerah Istimewa Yogyakarta. Penelitian ini dilakukan pada semester genap tahun pelajaran 2017/2018, yaitu pada tanggal 1122 Januari 2018 selama delapan hari. Subjek penelitian yang digunakan dalam penelitian SSR ini sebanyak satu orang, yaitu siswa berinisial " $D$ " kelas VIII D di SMP Negeri 3 Sewon yang memiliki kepribadian introvert dan memiliki kesulitan dalam menerima pembelajaran matematika. Pemilihan siswa tersebut berdasarkan hasil analisis pendahuluan dalam bentuk tes awal, wawancara terhadap siswa, dan guru yang mengajar mahasiswa tersebut. 
Proses pengumpulan data penelitian dibagi menjadi dua bagian besar, yaitu fase baseline dan intervensi. Fase baseline dilakukan selama 4 hari dengan durasi waktu 45 menit per sesi per hari. Pada fase ini, seorang siswa introvert diberikan tes kemampuan berpikir kritis matematis pada materi Phytagoras. Data hasil tes ini digunakan sebagai data awal siswa sebelum diberikan perlakuan. Selanjutnya, fase intervensi dilakukan selama 4 hari dengan durasi waktu 90 menit per sesi per hari. Pada fase ini, seorang siswa introvert diberikan perlakuan berupa kegiatan belajarmengajar menggunakan model PBL, yang dilanjutkan dengan tes kemampuan berpikir kritis matematis setelah diberikan perlakuan.

Pelaksanaan baseline dilakukan selama empat kali. Fase ini dilakukan untuk mengungkapkan kondisi awal subjek yaitu kemampuan berpikir kritis matematis subjek dengan kepribadian introvert pada materi phytagoras. Perolehan skor persentase hasil tes pada baseline ini diperoleh dari jumlah skor yang didapat subjek dibagi jumlah skor maksimal dikali $100 \%$. Pengambilan data pada fase baseline ini dilakukan selama empat pertemuan. Fase baseline dilakukan peneliti diruang perpustakaan dan ruang kelas. Peneliti menyiapkan alat tulis yang dibutuhkan oleh subjek dalam mengerjakan soal tes kemampuan berpikir kritis matematis pada materi phytagoras. Setiap pertemuan dilakukan pengambilan data melalui tes kemampuan berpikir kritis matematis dengan bentuk soal uraian. Setiap sesi pertemuan pada fase baseline subjek diberikan waktu 45 menit untuk menyelesaikan tes kemampuan berpikir kritis matematis. Sedangkan, pada fase intervensi atau pelakuan yang diberikan dalam penelitian SSR ini menggunakan model PBL pada pembelajaran phytagoras.

Pada penelitian SSR ini variabel bebasnya adalah penerapan model pembelajaran PBL dan variabel terikatnya adalah kemampuan berpikir kritis matematis siswa introvert. Teknik pengumpulan data pada penelitian ini dibagi menjadi 3 bagian besar, yaitu tes (dilakukan pada fase baseline dan diakhir intervensi), observasi (dilakukan selama proses pembelajaran), dan wawancara (dilakukan selama dan akhir proses pembelajaran). Sedangkan, instrumen yang digunakan untuk mengumpulkan data berupa foto, video, dan hasil tes, adalah tes hasil belajar dan dokumentasi. Selanjutnya, data yang dikumpulkan di analisis berdasarkan 2 kondisi besar selama proses penelitian, yaitu analisis dalam kondisi dan antar kondisi. Analisis dalam kondisi meliputi komponen 
panjang kondisi (panjang interval), kecenderungan arah, tingkat stabilitas, tingkat perubahan, jejak data, dan rentang. Sedangkan, analisis antar kondisi meliputi jumlah variable yang diubah, perubahan kecenderungan arah dan efeknya, perubahan stabilitas dan efeknya, perubahan level data, serta data yang tumpang tindih (overlap).

\section{Temuan dan Pembahasan}

Hasil pengukuran kemampuan berpikir kritis matematis yang dilakukan oleh peneliti terhadap subjek selama delapan hari dapat dilihat pada Tabel 1. Terdapat dua fase dalam proses penelitian yang dilakukan, yakni fase $A$ (baseline) dan fase $B$ (intervensi).

Tabel 1. Skor subjek

\begin{tabular}{ccc}
\hline Baseline & Sesi & $\begin{array}{c}\text { Jumlah jawaban benar } \\
\text { (correct response) }\end{array}$ \\
\hline 11 Januari 2018 & 1 & 22 \\
12 Januari 2018 & 2 & 31 \\
13 Januari 2018 & 3 & 17 \\
15 Januari 2018 & 4 & 28 \\
\hline Intervensi & Sesi & Jumlah jawaban benar \\
& & (correct response) \\
\hline 16 Januari 2018 & 5 & 81 \\
19 Januari 2018 & 6 & 80 \\
20 Januari 2018 & 7 & 85 \\
22 Januari 2018 & 8 &
\end{tabular}

Pada sesi pertama sampai dengan sesi ke-empat yang menunjukkan fase A (baseline), skor yang didapatkan oleh subjek adalah 22, 31, 17, dan 28. Selanjutnya, pada sesi kelima sampai dengan sesi kedelapan skor yang didapatkan oleh subjek adalah 81, 82, 80, dan 85. Hasil skor yang diperoleh subjek dapat dilihat pada grafik yang tersedia dalam Gambar 1. 


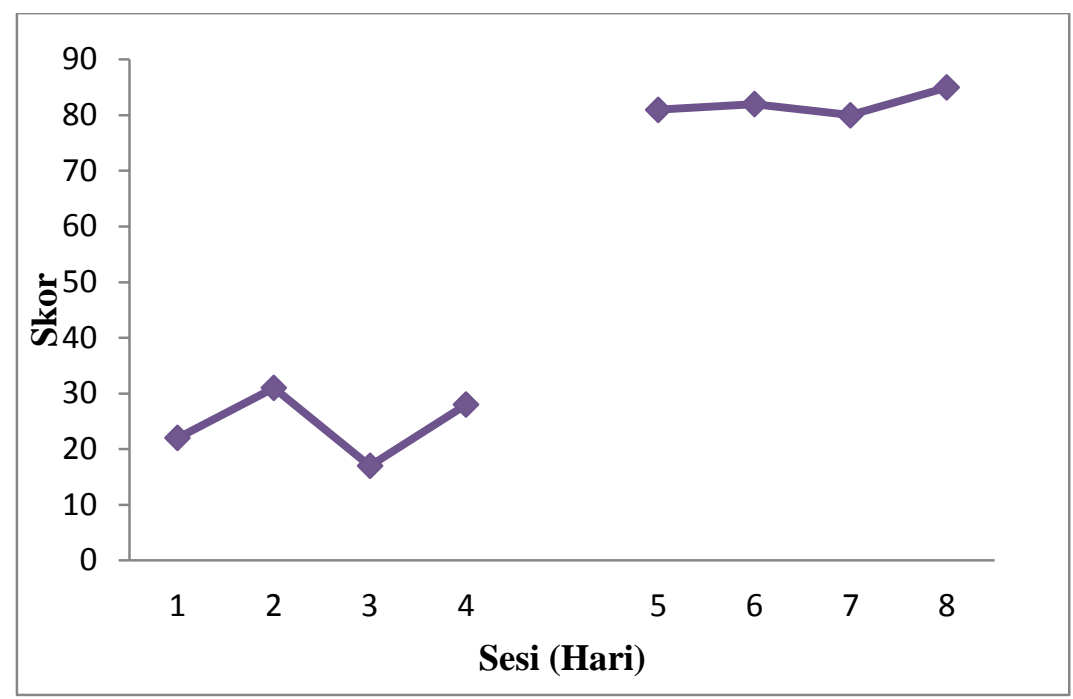

Gambar 1. Analisis visual baseline dan intervensi

Terdapat beberapa komponen penting yang harus dianalisis pada analisis dalam kondisi yakni meliputi komponen panjang kondisi (panjang interval), kecenderungan arah, tingkat stabilitas, tingkat perubahan, jejak data, dan rentang. Seluruh komponen ini dianalisis untuk mengetahui kondisi awal subjek penelitian. Peneliti harus memastikan bahwa subjek penelitian harus dalam kondisi awal yang stabil sebelum diberikan perlakuan. Adapun analisis dalam kondisi pada penelitian ini dapat dilihat pada Tabel 2.

Tabel 2. Rangkuman hasil analisis visual dalam kondisi

\begin{tabular}{lcc}
\hline \multicolumn{1}{c}{ Kondisi } & $\mathbf{A} / \mathbf{1}$ & $\mathbf{B} / \mathbf{2}$ \\
\hline $\begin{array}{l}\text { Panjang Kondisi } \\
\text { Estimasi Kecenderungan Arah }\end{array}$ & 4 & 4 \\
\cline { 2 - 3 } $\begin{array}{l}\text { Kecenderungan Stabilitas } \\
\text { Kecenderungan Jejak }\end{array}$ & Variable (0\%) & Stabil (100\%) \\
\cline { 2 - 3 } & - & + \\
Level Stabilitas dan Rentang & variabel & stabil \\
\cline { 2 - 3 } & $22,175-26,825$ & $75,625-88,375$ \\
Level Perubahan & $28-22=6$ & $85-81=4$ \\
\hline
\end{tabular}


Pada analisis antar kondisi, terdapat beberapa komponen penting yang harus dianalisis. Komponen-komponen tersebut antara lain jumlah variable yang diubah, perubahan kecenderungan arah dan efeknya, perubahan stabilitas dan efeknya, perubahan level data, serta data yang tumpang tindih (overlap). Untuk melakukan analisis antar kondisi yang pertama adalah memasukkan kode kondisi pada A (baseline) dengan B (intervensi), analisis antar kondisi dapat dilihat pada Tabel 3.

Tabel 3. Rangkungan hasil analisis visual antar kondisi

\begin{tabular}{lc}
\multicolumn{1}{c}{ Perbandingan Kondisi } & $\begin{array}{c}\mathbf{B}_{\mathbf{1}} / \mathbf{A}_{\mathbf{1}} \\
\mathbf{( 2 : 1 )}\end{array}$ \\
\hline $\begin{array}{l}\text { Jumlah variabel yang diubah } \\
\text { Perubahan kecenderungan arah } \\
\text { dan efeknya }\end{array}$ & 1 \\
Perubahan kecenderungan & Variable ke stabil \\
stabilitas & $28-81=-53$ \\
Perubahan level & $0 \%$ \\
Presentase overlap & \multicolumn{2}{c}{$0 \%$} \\
\hline
\end{tabular}

Berdasarkan hasil overlap, seperti tampak pada Tabel 3, dapat disimpulkan bahwa, semakin kecil prensentase overlap maka pengaruh intervensi terhadap target behavior semakin baik, yaitu kemampuan berpikir kritis matematis siswa introvert. Hal ini, sejalan dengan hasil penelitian Ulfah dan Prahmana (2018) dengan variabel terikat berupa kemampuan pemahaman matematis siswa dan variabel bebas berupa pembelajaran berbasis masalah, yang memiliki presentase overlap yang semakin kecil, sehingga perlakuan yang diberikan dapat meningkatkan kemampuan pemahaman matematis siswa. Overlap disini diartikan sebagai data hasil penelitian yang saling tumpang tindih.

Penggunaan model PBL yang dilaksanakan dalam penelitian ini adalah pada materi phytagoras. Pada setiap sesi dalam fase baseline subjek diminta untuk menyelesaikan soal-soal untuk mengukur kemampuan awal subjek terhadap materi tersebut. Hasil yang diperoleh pada fase ini yakni subjek belum mengembangkan secara optimal kemampuan berpikir kritis matematisnya. Hal ini dapat dilihat pada Gambar 2. 


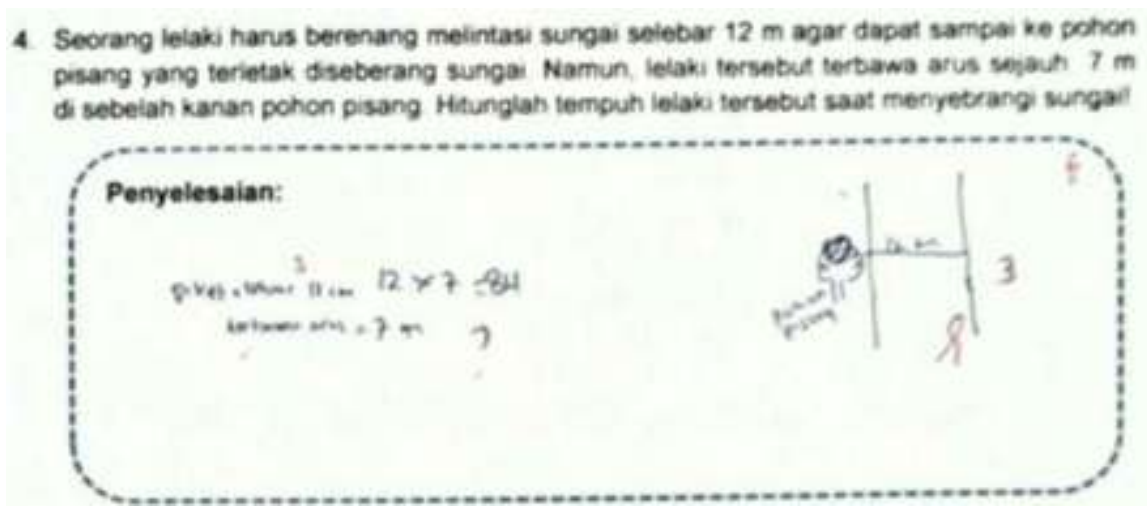

Gambar 2. Soal dan penyelesaian baseline

Berdasarkan Gambar 2 subjek perlu mengembangkan kemampuan berpikir kritis matematisnya secara optimal, hal ini disebabkan oleh subjek yang belum mengumpulkan informasi secara lengkap berdasarkan pemasalahan yang diberikan sehingga terdapat kesalahan dalam mengolah informasi tersebut. Diketahui bahwa subjek menggambar sebuah sungai dengan lebar $12 \mathrm{~m}$, kemudian terdapat pohon dipinggir sungai. Hal yang dapat ditangkap oleh peneliti adalah subjek menganggap bahwa "lelaki terbawa arus sejauh $7 \mathrm{~m}$ " sama dengan panjang sungai. Sehingga, dengan pengetahuan yang telah dimilikinya yakni rumus luas persegi panjang subjek langsung mengalikan $12 \mathrm{~m} \times 7 \mathrm{~m}$. Oleh karena itu, pada fase intervensi subjek dibimbing untuk mengembangkan kemampuan berpikir kritis matematisnya menggunakan model PBL.

Selanjutnya, pada setiap sesi dalam fase intervensi subjek diberikan perlakuan (treatment) yang menggunakan model PBL. Pada fase tersebut subjek diberikan masalah yang berkaitan dengan materi phytagoras sehingga subjek melalui sebuah proses yakni, mendefinisikan masalah, mengumpulkan masalah, dan mendapatkan solusi, sampai dengan membuat kesimpulan (Rusman, 2014). Hal ini yang dimaksud dengan subjek dapat mengembangkan kemampuan berpikir kritis matematisnya. Setelah diberikan perlakuan subjek kembali diminta untuk menyelesaikan soal sehingga peneliti dapat mengukur kemampuan berpikir kritis matematis subjek setelah diberikan perlakuan. Hasil penelitian (Rahmazatullaili, Zubainur, \& Munzir, 2017) juga menunjukkan bahwa kemampuan berpikir kreatif dan pemecahan masalah siswa setelah 
penerapan model project based learning lebih baik dari sebelum penerapan. Hasil yang diperoleh pada fase berikut, yakni subjek terlihat sudah dapat menyelesaikan soal yang diberikan. Hal ini dapat dilihat pada Gambar 3.

3. Joni berenang menyeberangi sebuah sungai dengan lebar 12 meter, sesampainya di seberang. ternyata Joni telah terbawa arus sejauh 5 meter. Tentukan jarak yang ditempuh Joni saat menyeberangi sungai tersebut.

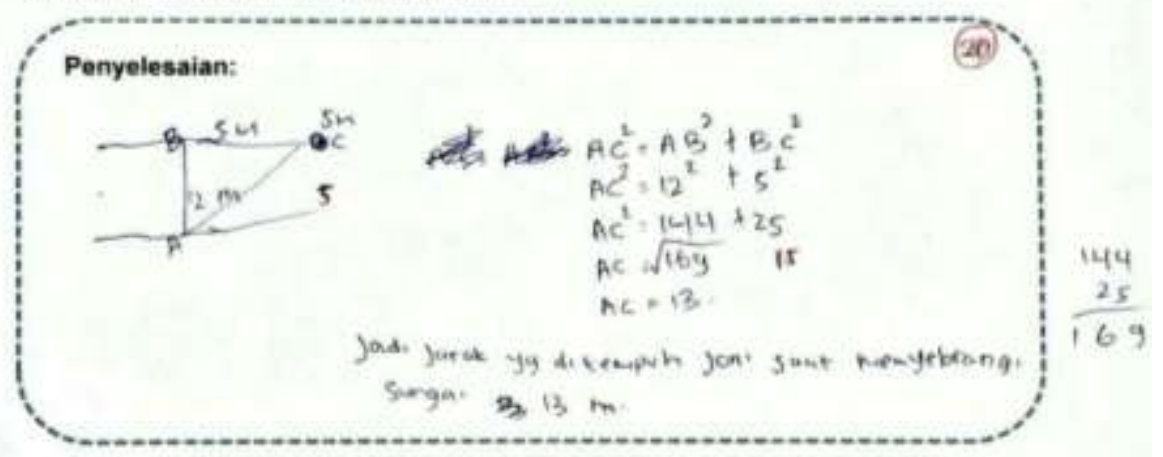

Gambar 3. Soal dan penyelesaian intervensi

Berdasarkan Gambar 3 Subjek telah mampu memenuhi beberapa indikator kemampuan berpikir kritis matematis. Subjek telah menentukan strategi dan taktik unyuk menyelesaikan masalah pada tahap awal dengan terlebih dahulu menggambarkan ilustrasi dari permasalahan yang diberikan. Selain itu, subjek juga membuat penjelasan lebih lanjut dengan mensubtitusikan infomasi yang telah diketahui kedalam rumus phytagoras untuk menyelesaikan masalah tersebut. Subjek juga memberikan kesimpulan pada akhir penyelesaian masalah. Sehingga, peneliti dapat menyatakan bahwa perlahan-lahan subjek telah mengembangkan kemampuan berpikir matematisnya.

Selama sesi intervensi dalam penelitian ini juga memperoleh hasil bahwa setelah diberikan perlakuan (treatment) berupa penggunaan model PBL, subjek terlihat lebih antusias walaupun belum sepenuhnya aktif dalam mengikuti pembelajaran. Selanjutnya, selama pemberian perlakuan, proses belajar mengajar menjadi lebih interaktif. Hal ini juga diungkapkan oleh Rahman (2017) bahwa pembelajaran yang interaktif dapat memunculkan keberanian siswa dalam menyampaikan hasil pekerjaannya. Sehingga, subjek yang diketahui berkepribadian introvert 
antuasias dalam proses pembelajaran. Pernyataan ini didukung oleh Raufany, Solfitri, dan Siregar (2018) yang mengungkapkan bahwa dengan menerapkan model PBL dapat mengaktifkan siswa dalam memahami permasalahan dan meningkatkan proses pembelajaran sehingga hasil belajar matematika siswa meningkat.

Berdasarkan hasil penelitian diketahui bahwa pembelajaran yang berlangsung menggunakan model PBL dengan materi phytagoras terhadap siswa introvert menghasilkan proses pembelajaran yang dapat meningkatkan kemampuan berpikir kritis matematis. Hal ini ditunjukkan dengan adanya peningkatan skor yang diperoleh subjek setelah adanya fase intervensi berupa pemberian pelakuan berupa model PBL.

\section{Simpulan}

Siswa dengan kepribadian introvert dapat menyelesaikan permasalahan yang diberikan berupa materi teorema phytagoras dengan menggunakan model PBL. Hasil evaluasi sebelum dan sesudah perlakuan menunjukkan peningkatan yang signifikan terhadap kemampuan berpikir kritis matematis, sehingga perlakuan yang diberikan dapat meningkatkan kemampuan berfikir kritis matematis siswa introvert.

\section{Ucapan Terima Kasih}

Peneliti mengucapkan banyak terima kasih kepada pihak sekolah SMP Negeri 3 Sewon yang telah mengizinkan peneliti untuk melakukan penelitian di kelas VIII D tahun ajaran 2017/2018. Selain itu, terima kasih juga kepada guru pamong yang telah mendampingi dan membantu selama penelitian ini.

\section{Daftar Pustaka}

Anggraeni, I.K. \& Khabibah, S. (2014). Profil kemampuan koneksi matematika siswa dalam menyelesaikan masalah kontekstual ditinjau dari kemampuan matematika. MATHEdunesa: Jurnal Ilmiah Pendidikan Matematika, 3(3), 107-113.

Anwar, M. H., Sa'dijah, C., \& Subanji, S. (2017). Media pohon matematika untuk meningkatkan berpikir kritis siswa sekolah dasar. in prosiding seminar nasional mahasiswa kerjasama direktorat jenderal guru dan tenaga kependidikan kemendikbud 2016. Malang: Universitas Negeri Malang. 
Arifin, Z. (2016). Pengembangan instrumen pengukur berpikir kritis matematika siswa SMA kelas X. Theorems, 1(1), 58-74.

Cahdriyana, R. A. (2016). Pengaruh metode pembelajaran berbasis masalah terhadap kemampuan memecahkan masalah matematika siswa SMP Negeri 9 Yogyakarta. AdMathEdu, 6(2), 177-188.

Fatmawati, H., \& Triyanto, T. (2014). Analisis berpikir kritis siswa dalam pemecahan masalah matematika berdasarkan polya pada pokok bahasan persamaan kuadrat (penelitian pada siswa kelas X SMK Muhammadiyah 1 Sragen tahun pelajaran 2013/2014). Jurnal Pembelajaran Matematika, 9(2), 911-922.

Hasanah, N., Mardiyana, \& Sutrima. (2013). Analisis proses berpikir siswa dalam memecahkan masalah matematika ditinjau dari tipe kepribadian extrovert-introvert dan gender. Jurnal Pembelajaran Matematika, 1(4), 422-434.

Marwan, M., \& Ikhsan, M. (2016). Meningkatkan kemampuan berpikir kritis matematis siswa SMK melalui model pembelajaran berbasis masalah. Jurnal Didaktik Matematika, 3(2), 9-18.

Naafidza, J. H., \& Arief, A. (2016). Identifikasi tingkat berpikir kritis siswa dalam menyelesaikan soal-soal fisika berdasarkan tipe kepribadian. Jurnal Inovasi Pendidikan Fisika, 5(1), 17-21.

Novitawati \& Irfan. A. N. (2014). Meningkatkan hasil belajar penjumlahan pecahan melalui model problem based learning dengan kombinasi numbered heads together pada siswa kelas IV SDN Mawar 7 Banjarmasin. Jurnal Paradigma, 9(2), 83-92.

Rahman, H. T. (2016). Efektivitas penggunaan metode pendidikan matematika realistik indonesia terhadap kemampuan berhitung pembagian bagi siswa autistik kelas IV SD di SLB Tegar Harapan Yogyakarta. Skripsi. Yogyakarta: Universitas Negeri Yogyakarta. Diakses di http://eprints.uny.ac.id/44189/

Rahmazatullaili, R., Zubainur, C., \& Munzir, S. (2017). Kemampuan berpikir kreatif dan pemecahan masalah siswa melalui penerapan model project based learning. Beta Jurnal Tadris Matematika, 10(2), 166-183. Doi:10.20414/betajtm.v10i2.104

Raufany, G., Solfitri, T., \& Siregar, S. N. (2018). Penerapan model problem based learning untuk meningkatkan hasil belajar matematika siswa kelas X IPA 1 SMA Negeri 2 Pekanbaru. Jurnal Online Mahasiswa (JOM) Bidang Keguruan dan Ilmu Pendidikan, 5(1), 1-10.

Rusman, D. (2014). Model-Model Pembelajaran. Jakarta: Raja Grafindo.

Sunanto, J., Takeuchi, K., \& Nakata, H. (2006). Penelitian dengan Subjek Tunggal. Jepang: Universitas Tsakuba.

Sunarsih, S. (2012). Pembelajaran keterampilan berbicara model kooperatif teknik mencari pasangan dan teknik kancing gemerincing pada siswa introver dan ekstrover di SMP. Seloka: Jurnal Pendidikan Bahasa dan Sastra Indonesia, 1(1), 35-39. 
Syahbana, A. (2012). Peningkatan kemampuan berpikir kritis matematis siswa smp melalui pendekatan contextual teaching and learning. EDUMATICA/ Journal Pendidikan Matematika, 2(1), 45-57.

Ulfah, A. F., \& Prahmana, R. C. I. (2018). Single subject research: Implementasi pembelajaran berbasis masalah terhadap pemahaman matematis siswa. Jurnal Elemen, 4(1), 105-118.

Yanti, O. F., \& Prahmana, R. C. I. (2017). Model problem based learning, guided inquiry, dan kemampuan berpikir kritis matematis. JRPM (Jurnal Review Pembelajaran Matematika), 2(2), 120-130.

Yuwono, A. (2010). Profil siswa SMA dalam memecahkan masalah matematika ditinjau dari tipe kepribadian. Tesis. Surakarta: Universitas Sebelas Maret.

Diakses

di http://eprints.uns.ac.id/7294/1/131790608201008281.pdf 